ISSN $2230-8695$

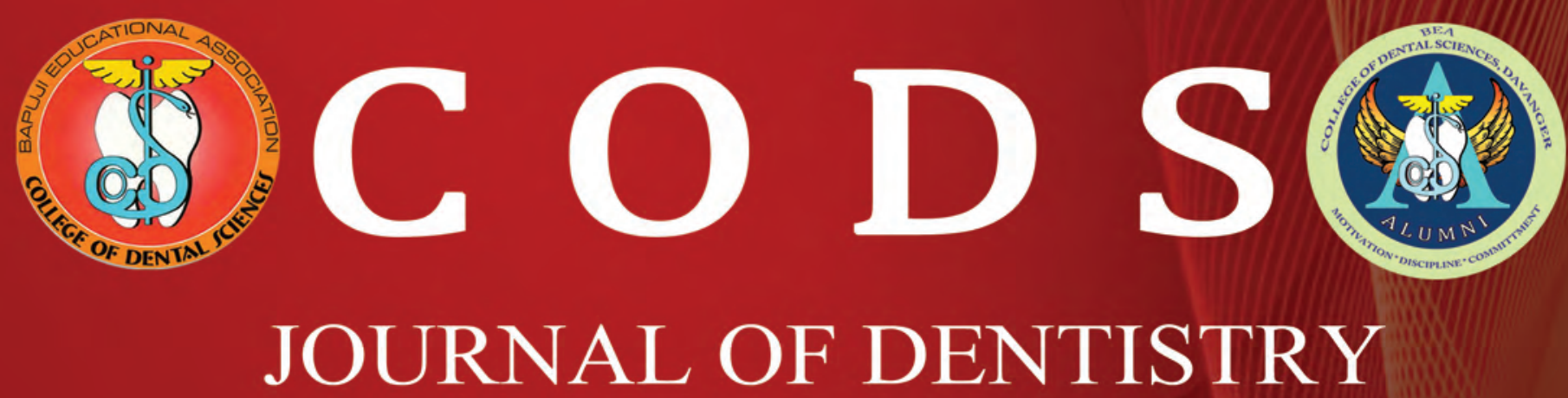

Official Publication of College of Dental Sciences Alumni Association, Davangere.

Volume $6 \cdot$ Issue $1 \bullet 2014$ 


\section{CODS Journal of Dentistry}

Official Publication of College of Dental Sciences Alumni Association, Davanagere

Volume 6, Issue 1, 2014

\section{CONTENTS}

Director's Message

V.V. Subba Reddy

President's Message

Vasundhara Shivanna

Secretary's Message

Praveen S. Basandi

Editorial

Nandini D.B

\section{Original Articles}

Effect of alcohol containing and alcohol free mouth rinses on microhardness of three esthetic restorative materials

Vasundhara Shivanna, Rucha Nilegaonkar

Prevalence and distribution of dental anomalies and fluorosis in a small cohort of

Indian school children and teenagers

Selvamani. M, Praveen S Basandi, Madhushankari G.S

\section{Review Articles}

Paperless dentistry - The future

Mala Ram Manohar, Gajendra Bhansali

Photo activated disinfection in restorative dentistry - A technical review

Deepak B.S, Mallikarjun Goud K, Nishanth P

An overview of occupational hazards in dental practice and preventive measures.

Poorya Naik .D.S, Chetan .S, Gopal Krishna.B.R, Naveen Shamnur

An overview on influences of estrogen and progesterone on periodontium 


\section{CODS Journal of Dentistry}

Official Publication of College of Dental Sciences Alumni Association, Davanagere

\section{Volume 6, Issue 1, 2014}

\section{CONTENTS}

\section{Review Articles}

Dental home - A new approach for child oral health care

Poornima P, Meghna Bajaj, Nagaveni N.B, Roopa K.B, V.V. Subba Reddy

Variants of inferior alveolar nerve block: A review

Anuradha M, Yashavanth Kumar D.S, Harsha .V. Babji, Rahul Seth

\section{Case Reports}

Ellis-van Creveld syndrome affecting siblings: A case report and review

Mamatha G.P, Manisha Jadhav , Rajeshwari G Annigeri, Poornima .P, V.V Subba Reddy

Integrated approach of ceramic and composite veneers in tetracycline

stained teeth: A case report.

Divya K.T, Satish .G

Fibrous dysplasia of right maxilla: A case report and review of literature

Guruprasad .L, Kavita Rao, Uma Devi H.S, Priya N.S

A case report of recurrent herpetic gingivostomatitis; with special reference to the role of cytology in diagnosis

Pramod K Jali, Nandini D.B, Mohan K.P, Madhushankari G.S

Eagle's syndrome with type III segmented styloid process : A case report.

Usha V. A, Mamatha G. P, Maria Priscilla David, 


\title{
Photo activated disinfection in Restorative Dentistry: A technical review
}

\author{
Deepak BS ${ }^{1}$, Mallikarjun Goud K², Nishanth $\mathrm{P}^{3}$
}

Professor $^{1,2}$, Post-Graduate student ${ }^{3}$

Dept. of Conservative Dentistry \& Endodontics, Bapuji Dental College \& Hospital, Davangere.

\begin{abstract}
:
The purpose of this review is to summarize the recent developments regarding photodynamic therapy (PDT) in the field of restorative dentistry. A search of pertinent literature was carried out in PubMed to determine the current applications of photo activated disinfection (PAD) in dentistry. This overview will provide the practitioners, the current status and use of PAD. Within the limitations of the present review, it can be concluded that although PAD cannot replace antimicrobial therapy at its current stage, it may be used as an adjunctive tool in restorative dentistry. Further long-term clinical studies are necessary in establishing a more specific place of the technique in the field of dentistry.
\end{abstract}

\section{Keywords:}

Photodynamic therapy, photosensitizing agent, photo activated disinfection, lactobacilli, streptococcus mutans.

\section{Introduction:}

In recent years, the emergence of antibiotic resistant strains, such as methicillin resistant Staphylococcus aureus and vancomycin-resistant Enterococcus faecalis, stimulated a search for alternative treatments. Photodynamic therapy (PDT) has the potential to be such an alternative, especially for the treatment of localized infections of the skin and the oral cavity. Microorganisms that are killed by photo activated disinfection (PAD) include bacteria, fungi, viruses, and protozoa. ${ }^{1}$

Photo dynamic therapy (PDT) involves the use of low power lasers with appropriate wave length to kill microorganisms treated with a photo sensitizer drug. Photodynamic antimicrobial chemotherapy (PACT) uses a visible light source with photo sensitizer (Fig 1). ${ }^{2}$

The development of resistance to PACT appears to be unlikely, since, in microbial cells singlet oxygen and free radicals interact with several cell structures and different metabolic pathways. PACT is equally effective against antibiotic-resistant and antibiotic- susceptible bacteria.

\section{Corresponding author:}

Dr. Deepak B.S.

Professor

Dept. of Conservative Dentistry \& Endodontics Bapuji Dental College \& Hospital, Davanagere Email Id:deepakdvg@yahoo.com

Ph no: 9886177373
PACT is a process in which microorganisms are treated with a photosensitizing drug and then irradiated with low-intensity visible light of the appropriate wavelength. ${ }^{3,4}$

Fig 1: PACT




The photosensitizer can be delivered to infected areas by topical application, instillation, interstitial injection, or aerosol delivery. The bacterias that can be destroyed include total Streptococci, Actinomyces, Lactobacillus, Prevotella intermedia, Peptostreptococcus micros, Fusobacterium nucleatum and Enterococcus faecalis. ${ }^{5}$ Photosensitizer compound in its ground state is activated by light and transformed into a high energized triplet state.

\section{Two mechanisms of action explain the effectiveness of PACT:}

The triplet compound interacts with the cell's organic substrate molecule, producing free radicals and radical ions. These in turn react with endogenous oxygen and reactive oxygen species (ROS) such as hydrogen peroxide and hydroxyl radicals which irreversibly damage the cell membrane. ROS compounds can also damage subcellular organelles and enzymes as well as DNA.

The triplet compound interacts directly with the molecular oxygen to produce singlet oxygen, which is highly reactive. It also causes irreparable cellular damage including the cell wall. Although both mechanisms exist in relation to each other, singlet oxygen generally produces the lethal bacterial effects of PACT. The interaction is extremely rapid, since the radius of action of singlet oxygen is estimated to be on the order of 0.01 to $0.02 \mu \mathrm{m}$, corresponding to a lifetime of 0.01 to $0.04 \mu \mathrm{m}$ in cells. ${ }^{6}$

Photodynamic antimicrobial chemotherapy in a suitably administered photosensitizer may be seen to have the following advantages over "conventional” laser use:

- Nonsurgical (sub ablative) photonic energy values employed

- Primary (indirect) interaction through chemical mediator (photosensitizer)

- Little risk of collateral damage within confined target sites.

- The use of non-collimated light through a diffuser tip can overcome limited access and be further compensated by scatter through the body of the liquid sensitizer. There is limited migration of the molecule from its formative site, thus its effect is much localized. The advantage is that surrounding structures can be preserved; however, the placement of the photosensitizer should be as close to the infection as possible.?
Other applications of PACT:

- Tooth surface disinfection prior to dental treatment.

- Disinfection of infected root canals in endodontics

- Periodontology

- Gingivitis and pericoronitis

- Peri-implantitis $^{8}$

- Treatment of candidiasis

- Treatment of superficial precancers and cancers

\section{Table 1: Various studies done by authors using PACT}

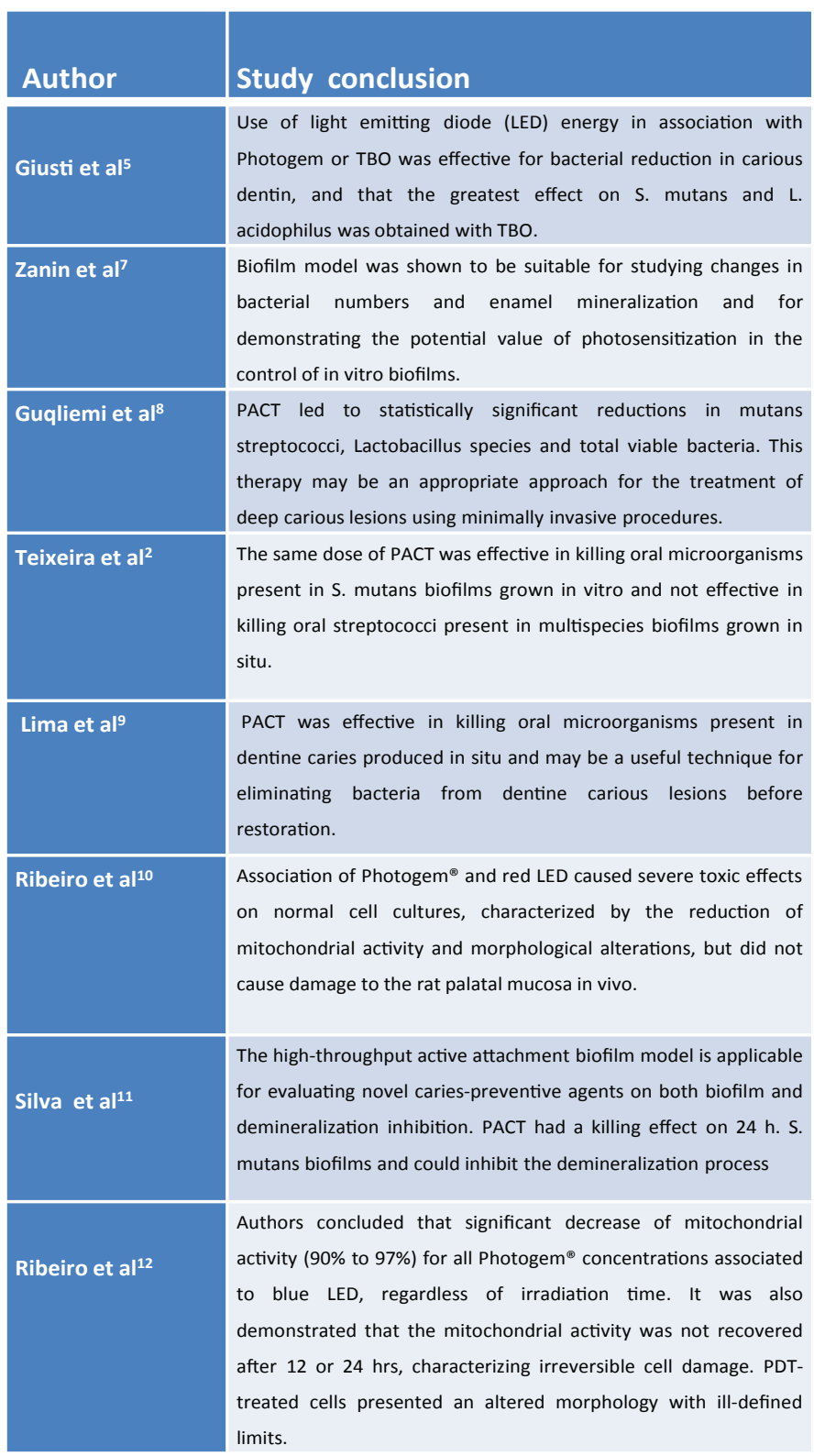




\section{Conclusion:}

In vitro studies and experimental models have shown PACT to be effective on S. mutans and lactobacilli, most commonly isolated microorganisms in carious dentin. Further in vivo studies and human trails, has to be done before this therapy can be used for the management of deep carious lesions with minimally invasive procedures.

\section{References:}

1. Wainwright M. Photodynamic antimicrobial chemotherapy. J Antimicrob Chemother 1998; 42:13-28.

2. Teixeira AH, Pereira ES, Rodrigues LK, Saxena D, Duarte S, Zanin IC Effect of Photodynamic Antimicrobial Chemotherapy on in vitro and in situ Biofilms. Caries Res 2012;46:549-54.

3. Hecker S, Hiller KA, Galler KM, Erb S, Mader T, Schmalz G. Establishment of an optimized ex vivo system for artificial root canal infection evaluated by use of sodium hypochlorite and the photodynamic therapy. Int Endod J. 2013;46:449-57.

4. Haapasalo M, Orstavik D. In vitro infection and disinfection of dentinal tubules. J Dent Res 1987;66:1375-9.

5. Giusti JS, Santos-Pinto L, Pizzolito AC, Helmerson K, Carvalho-Filho E, Kurachi C et al. Antimicrobial Photodynamic Action on Dentin Using a Light-Emitting Diode Light Source. Photomedicine and Laser Surgery 2008;26: 281-7.

6. Pfitzner A. Bacterial killing by Photodynamic therapy. J Periodontol 2006;75:1343-49.

7. Zanin IC, Lobo MM, Rodrigues LK, Pimenta LA, Hofling JF, Goncalves RB. photosensitization of in vitro biofilms by toluidine blue $\mathrm{O}$ combined with a light-emitting diode. Eur J Oral Sci. 2006; 114:64-9.

8. Gugliemi Cde A, Simionato MR, Ramalho KM, Imparto JC, Pinheiro SL, Luz MA. Clinical use of photodynamic antimicrobial chemotherapy for the treatment of deep carious lesions. J Biomed Opt. 2011;16(8) 088003. doi: 10.1117/1.3611009.

9. Lima JP, Sampaio de Melo MA, Borges FM, Teixeira AH, Steiner-Oliveira C, Nobre Dos Santos M, et al. Evaluation of the antimicrobial effect of photodynamic antimicrobial therapy in an in situ model of dentine caries. Eur J Oral Sci. 2009; 117:568-74.

10.Ribeiro AP, Pavarina AC, Trindade FZ, Bagnato VS, Kurachi C, Souza Costa CA. Cellular and tissue effects induced by photogem ${ }^{\circledR}$ and red LED in photodynamic therapy. Laser physics 2011; 21:229-38.
11.Silva TC, Pereira AF, Exterkate RA, Bagnato VS, Buzalaf MA, Machado MA, et al. Application of an active attachment model as a high-throughput demineralization biofilm. J Dent. 2012; 40:41-7.

12.Ribeiro AP, Pavarina AC, Trindade FZ, Inada NM, Bagnato VS, de Souza Costa CA Photodynamic therapy associating Photogem ${ }^{\circledR}$ and blue LED on L929 and MDPC-23 cell culture. Cell Biol Int. 2010; 34:343-51.

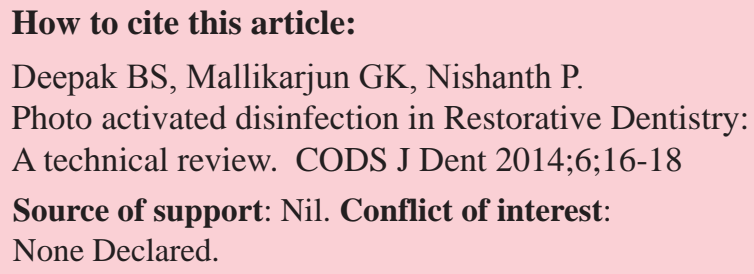

